\title{
MANAJEMEN SAMPAH PADAT DI KOTA BANDUNG DAN METODE ALTENATIF PENGOLAHANNYA
}

\author{
Sunasih Mulianingsih \\ Institut Pemerintahan Dalam Negeri (IPDN) \\ Email: sunasihmulianingsih@ipdn.ac.id
}

\begin{abstract}
Abstrak
Permasalahan pengelolaan sampah perkotaan di Kota Bandung telah menjdi masalah yang tidak terpecahkan sampai saat ini. Pertumbuhan penduduk yang pesat ditambah pendatang yang banyak tiba di Kota Bandung telah menambah produksi sampah dari tahun ke tahun. Menurut Dinas Lingkungan Hidup dan Kebersihan Kota Bandung menghasilkan sekitar 1477 metrik ton sampah padat per hari, dimana $63 \%$ adalah bahan organik. Pengumpulan sampah di Kota Bandung di kelola oleh pemerintah kota melalui BUMD (PD Kebersihan) yang berwenang. Sekitar 44,3\% dari pengelolaan sampah padat di Kota Bandung dikomposkan untuk menghasilkan bahan pupuk, 54,7\% ditolak dan dibuang di tempat pembuangan akhir. Sampah non organik sebesar 23\% sebagian besar di daur ulang dan sekitar 11,3\% di bawa ke tempat pembuangan akhir, sementara sampah Residu seperti B3 sebesar 14\% ditimbun. Investigasi ini juga mencakup analisis manfaat ekonomi yang dapat direalisasikan dengan menerapkan insinerasi dan diskusi tentang tantangan yang dihadapi di Kota Bandung untuk menerapkan perubahan pada sistem manajemen persampahan perkotaan.
\end{abstract}

Kata Kunci: Manajemen Pengolahan, Sampah Padat Perkotan (SPP), Tempat Pembuangan Akhir, Sampah Organik, Sampah Non Organik, Insinerasi.

\begin{abstract}
The problem of mucipal waste management in the city of Bandung has been an unsolved problem to date. The rapid population growth plus many new arrivals to the city of Bandung have increased waste production from year to year. According to the Department of Environment and Sanitation, the city of Bandung produces around 1477 metric tons of solid waste per day, of which $63 \%$ is organic matter. Garbage collection in the city of Bandung is managed by the city government through the BUMD which handles it. About $44.3 \%$ of solid waste management in Bandung city is composted to produce fertilizer material, $54.7 \%$ is rejected and dumped in landfills. 23\% of non-organic waste is mostly recycled and around $11.3 \%$ is taken to landfills, while $14 \%$ of residual waste such as B3 is dumped. This investigation also includes an analysis of the economic benefits that can be realized by implementing incineration and a discussion of the challenges faced in the city of Bandung to implement changes to the existing urban solid waste management system.
\end{abstract}

Keywords: Processing Management, Municipal Solid Waste (MSW), Final Disposal Site, Organic Waste, Non Organic Waste, Inseneration.

\section{A. PENDAHULUAN}

Manajemen pengolahan sampah padat perkotaan (SPP) merupakan masalah lingkungan yang serius di negara berkembang (Wilson dkk, 2006; Ahsan dkk., 2014; Thi dkk., 2015; Sudaryanto dkk., 2010). Secara umum, pengelolaan persampahan perkotaan 
mencakup enam elemen dasar dari timbunan sampah: penyimpanan di tempat, pengumpulan, pemindahan dan pengangkutan, pemrosesan dan pemulihan dan, pada akhirnya, pembuangan residu dan sampah padat lainnya yang tidak dapat dipulihkan secara ekonomis untuk didaur ulang atau digunakan kembali (Narayana, 2009). Di masa lalu, banyak penelitian telah membahas pengelolaan sampah padat di Indonesia (Sulistyorini, 2005; Sari, 2017; Wahyono, 2001).

Diakui sebagai langkah besar untuk menerapkan pembuangan sampah padat yang tepat di Indonesia, undang-undang pengelolaan sampah nasional yaitu Undang-undang nomor 18 Tahun 2008 tentang pengelolaan sampah diberlakukan mulai 07 Mei 2008 (Indonesia, 2008). Pasal 9 menyebutkan bahwa semua pemerintah kabupaten dan kota memiliki kewenangan dalam menentukan arah kebijakan dan strategi dalam pengelolaan sampah; menyelenggarakan pengelolaan sampah; mengawasi dan mengevaluasi tata kelola pengolahan sampah tersebut. Dalam Undang-undang tersebut juga secara lengkap mengatur segala macam bentuk hak kewajban sampai sangsi yang tegas bagi masyarakat dan pemangku kepentingan yang terlibat dalam pengelolaan sampah tersebut.Meskipun undang-undang tersebut berlaku untuk seluruh wilayah di Indonesia, pemerintah kota tetap bertanggung jawab atas manajemen persampahan perkotaan.

Menjadi ibu kota Provinsi Jawa Barat dan juga kota pariwisata sekaligus kota pelajar, Bandung yang terletak sekitar $150 \mathrm{~km}$ dari Jakarta ibukota Negara Republik Indonesia dan berada di koordinat 1070 Bujur Timur dan 60 55' Lintang Selatan. Menurut Badan Pusat Statistik tahun 2018, penduduk kota Bandung adalah sekitar 2,5 juta jiwa dengan 1,26 juta jiwa laki-laki dan 1,24 juta jiwa perempuan (BPS, 2018). Bandung sebagai kota pariwisata dianugerahi keindahan alam dan juga peninggalan cagar budaya yang sangat banyak. Sebagai kota pelajar dan pendidikan, kota bandung banyak mempunyai perguruan tinggi yang cukup terkemuka di Indonesia. Melihat status kota Bandung sebagai kota pariwsata dan pelajar maka wajar Kota bandung sering dikunjungi wisatawan yang berasal dari luar baik luar kota maupun luar provinsi bahkan luar negeri. Banyaknya pendatang ini ditambah dengan penduduk kota bandung yang memang sudah banyak tentu menimbulkan permasalahan sampah yang tidak kecil. Maka untuk itu perlu di rumuskan manajemen pengelolaan sampah yang tepat.

Pertumbuhan sampah padat perkotaan (SPP) di Kota Bandung terus meningkat baik jumlah maupun variasinya. Karakteristik dan kuantitas SPP yang timbul dari kegiatan domestik, komersial dan industri di wilayah tersebut tidak hanya sebagai akibat dari 
pertambahan penduduk, peningkatan taraf hidup dan perkembangan teknologi, tetapi juga sebagai akibat dari kelimpahan dan jenis sumber daya alam di wilayah tersebut (Das \& Bhattacharyya, 2013; Giannis dkk., 2012).

Manajemen persampahan perkotaan yang tidak memadai sehubungan dengan daur ulang sampah padat, teknologi pengolahan, dan strategi pengelolaan menyebabkan kerugian ekonomi dan menghadirkan ancaman terhadap kesehatan masyarakat dan sumber daya lingkungan (Sejati, 2009; Marliani, 2015). Seperti di negara berkembang lainnya, kurangnya investasi yang memadai dan salah urus sumber daya keuangan di kawasan tetap menjadi hambatan utama untuk meningkatkan infrastruktur persampahan (Dwiyanto, 2011).

Studi ini adalah bertujuan mengkarakterisasi jumlah dan komposisi sampah yang dihasilkan di kota Bandung, menilai praktik pengelolaan sampah perkotaan secara keseluruhan, dan meninjau metode, persyaratan dan tantangan untuk meningkatkan pengumpulan, pemisahan, daur ulang, pengolahan dan pembuangan sampah. Rekomendasi untuk perbaikan sistem diusulkan berdasarkan pengamatan yang dilakukan selama studi.

\section{B. METODE}

Untuk menyelidiki status pengelolaan sampah berkelanjutan di Bandung, kami menghubungi perwakilan dari instansi yang bertanggung jawab atas kegiatan di kota ini, yaitu DLHK Kota Bandung dan Perusahaan Daerah Kebersihan (PD Kebersihan). Kuisioner yang membahas berbagai masalah pengelolaan sampah berkelanjutan (termasuk pembuatan, pengumpulan, pemisahan, daur ulang, perawatan dan pembuangan) disiapkan dan didistribusikan kepada personel PD Kebersihan.

Penelitian ini bersifat kualitatif dengan metode deskripsi untuk memperoleh gambaraan tentang obyek yang di teliti (Sugiyono, 2010). Kami memperoleh data terkait yang diekstrak dari hasil kuesioner, observasi visual, laporan yang tersedia dan beberapa wawancara dengan pegawai yang bertugas di PD Kebersihan. Dalam hal ini, banyak informasi diperoleh tentang organisasi dan praktik Bandung saat ini untuk daur ulang sampah, pengomposan dan pembakaran.

\section{HASIL DAN PEMBAHASAN}

\section{Manajamen Sampah Padat Perkotaan}

Pengelolaan sampah padat, pengumpulan, pengolahan, dan pembuangan bahan padat yang dibuang karena telah memenuhi tujuannya atau tidak lagi berguna. Pembuangan sampah 
padat perkotaan yang tidak tepat dapat menciptakan kondisi tidak sehat, dan kondisi ini pada gilirannya dapat menyebabkan pencemaran lingkungan dan berjangkitnya penyakit yang ditularkan melalui vector yaitu, penyakit yang disebarkan oleh hewan pengerat dan serangga (Hasibuan, 2016). Tugas pengelolaan sampah padat menghadirkan tantangan teknis yang kompleks. Mereka juga menimbulkan berbagai masalah administrasi, ekonomi, dan sosial yang harus dikelola dan diselesaikan (Damanhuri \& Padmi, 2010).

Tingkat timbulan sampah padat sangat bervariasi. Di Amerika Serikat, misalnya, sampah kota dihasilkan dengan kecepatan rata-rata sekitar $2 \mathrm{~kg}$ (4,5 pon) per orang per hari. Jepang menghasilkan kira-kira setengah dari jumlah ini, namun di Kanada tarifnya adalah 2,7 kg (hampir 6 pon) per orang per hari (Jouhara dkk, 2017). Di beberapa negara berkembang, tarif rata-rata bisa lebih rendah dari $0,5 \mathrm{~kg}$ (1 pon) per orang per hari. Data ini mencakup sampah dari sumber komersial, kelembagaan, dan industri serta pemukiman. Tingkat sebenarnya dari timbulan sampah harus ditentukan dengan hati-hati saat komunitas merencanakan proyek pengelolaan sampah padat (Omran \& Gavrilescu, 2008).

Sebagian besar komunitas mengharuskan sampah rumah tangga disimpan dalam wadah yang tahan lama dan mudah dibersihkan dengan penutup yang rapat untuk meminimalkan serangan hewan pengerat atau serangga dan bau yang menyengat. Wadah logam atau plastik galvanis dengan kapasitas sekitar 115 liter (30 galon) biasanya digunakan, meskipun beberapa komunitas menggunakan wadah yang lebih besar yang dapat diangkat dan dikosongkan secara mekanis ke dalam truk pengumpul. Kantong plastik sering digunakan sebagai pelapis atau sebagai wadah sekali pakai untuk pengumpulan di tepi jalan. Di mana sejumlah besar sampah dihasilkan seperti di pusat perbelanjaan, hotel, atau gedung apartemen tempat sampah dapat digunakan untuk penyimpanan sementara sampai sampah dikumpulkan. Beberapa gedung perkantoran dan komersial menggunakan pemadat di tempat untuk mengurangi volume sampah (Buclet \& Godard, 2013).

Pengumpulan sampah padat yang tepat penting untuk melindungi kesehatan masyarakat, keselamatan, dan kualitas lingkungan. Ini adalah kegiatan padat karya, terhitung sekitar tiga perempat dari total biaya pengelolaan sampah padat. Pegawai publik sering kali ditugaskan untuk tugas tersebut, tetapi terkadang lebih ekonomis bagi perusahaan swasta untuk melakukan pekerjaan di bawah kontrak dengan pemerintah kota atau kolektor pribadi dibayar oleh pemilik rumah individu. Seorang pengemudi dan satu atau dua loader melayani setiap kendaraan pengumpul (Asase dkk, 2009). 
Jika tujuan akhir dari sampah tidak dekat dengan komunitas tempat sampah dihasilkan, satu atau lebih stasiun transfer mungkin diperlukan. Sebuah stasiun transfer adalah fasilitas pusat di mana sampah dari banyak kendaraan pengumpul digabungkan menjadi kendaraan yang lebih besar, seperti unit traktor-trailer. Trailer dengan atap terbuka dirancang untuk membawa sekitar 76 meter kubik (100 kubik yard) sampah yang tidak dipadatkan ke lokasi pemrosesan atau pembuangan regional. Trailer tipe compactor tertutup juga tersedia, tetapi harus dilengkapi dengan mekanisme ejector. Di stasiun tipe pembuangan langsung, beberapa truk pengumpul langsung masuk ke dalam kendaraan pengangkut. Di stasiun jenis pembuangan penyimpanan, sampah pertama-tama dikosongkan ke dalam lubang penyimpanan atau ke platform, dan kemudian mesin digunakan untuk mengangkat atau mendorong sampah padat ke dalam kendaraan pengangkut. Stasiun transfer besar dapat menangani lebih dari 500 ton sampah per hari (Burnley dkk, 2011).

Setelah dikumpulkan, sampah kota dapat diolah untuk mengurangi total volume dan berat material yang membutuhkan pembuangan akhir. Pengolahan mengubah bentuk sampah dan membuatnya lebih mudah ditangani. Ini juga dapat berfungsi untuk menjadi bahan kompos penyubur tanaman (Sampah Organik), serta energi panas, untuk didaur ulang atau digunakan kembali.

\section{Hasil Dan Komposisi Sampah Padat Perkotaan (SPP) Di Kota Bandung}

Jumlah dan jenis sampah yang dihasilkan sangat penting untuk diketahui guna merencanakan dan mengembangkan sistem pengelolaan sampah berkelanjutan yang tepat. Data yang tersedia menunjukkan bahwa total timbulan sampah di Kota Bandung adalah 1.477 metrik ton per hari, dimana hanya sekitar $23 \%$ yang dikumpulkan sebagai bahan daur ulang yang dipisahkan dari sumbernya, sedangkan sisanya metrik ton lainnya tidak dipisahkan (DLHK, 2018).

Total komposisi sampah padat yang diterima oleh pusat pembuangan selama periode 2017-2018 ditunjukkan pada Tabel 1.

Tabel 1 Komposisi Sampah Padat Kota Bandung Periode Tahun 2017-2018

\begin{tabular}{|c|c|c|c|}
\hline No & Jenis & Sumber & Persentase \\
\hline \multirow{4}{*}{1} & Kertas & 10 \\
\cline { 3 - 4 } & \multirow{4}{*}{ Non Organik } & Plastik & 18 \\
\cline { 3 - 4 } & Kaca & 1 \\
\cline { 3 - 4 } & & Karet Kulit & 0 \\
\cline { 3 - 4 } & & Kain tekstil & 1 \\
\cline { 3 - 4 } & & Logam & 2 \\
\cline { 3 - 4 } & & Lain-lain & 5 \\
\hline
\end{tabular}


ARTIKEL

\begin{tabular}{|c|c|c|c|}
\hline \multicolumn{3}{|c|}{ Sub total } & $\mathbf{3 7}$ \\
\hline \multirow{3}{*}{2} & \multirow{3}{*}{ Organik } & Kayu Ranting Daun & 8 \\
\cline { 3 - 4 } & & Sisa Makanan & 45 \\
\cline { 3 - 4 } & & Lain-lain & 10 \\
\hline \multicolumn{3}{|c|}{ Sub total } & $\mathbf{6 3}$ \\
\hline \multicolumn{3}{|c|}{ Total } & $\mathbf{1 0 0}$ \\
\hline
\end{tabular}

Sumber: Diolah Peneliti (2019)

Tabel 1 menunjukkan bahwa komposisi sampah yang di hasilkan perhari adalah sebanyak 63 persen merupakan sampah organik yang meliputi kayu ranting daun sebanyak $8 \%$, sisa makanan $45 \%$ dan lain-lain sebanyak $10 \%$ menunjukkan sebagai akibat padatnya jumlah penduduk yang bermukim di kota Bandung sehingga menyebabkan sampah rumah tangga yang dihasilkan juga sangat signifikan jumlahnya. Dari Tabel 1 juga dapat dilihat bahwa sampah non organik menyumbang 37 dari keseluruhan komposisi sampat padat kota Bandung yang dihasilkan dengan didominasi dengan sampah plastic dan kertas.

Secara umum, lebih dari 99\% sampah di kota Bandung terdiri dari sampah padat (SSP), dimana 63\% merupakan bahan organik (DLHK, 2018). Nilai yang relatif tinggi ini terutama disebabkan oleh pola makan umum penduduk, misalnya makanan yang lebih segar dan tidak dikemas seperti yang diperkenalkan oleh budaya Barat. Komponen utama SSP lainnya di Bandung adalah plastik Perubahan gaya hidup penduduk telah meningkatkan konsumsi dan pemborosan plastik selama beberapa tahun terakhir.

Selain bahan organik, kertas dan plastik (28\%) dan logam (2\%) masing-masing merupakan persentase sampah rumah tangga tertinggi dan terendah di Kota. Kualitas penting dari sampah padat di Kota Bandung adalah kadar airnya, yang dianggap sedang, dan bervariasi menurut musim. Misalnya, kadar air di SSP yang dihasilkan di bulan November hampir 24\%. Kadar air SSP di kota Bandung bervariasi menurut musim dan berkisar antara 24\% sampai 38\%; dengan demikian, kadar air di SSP yang dihasilkan pada bulan November hampir $14 \%$ lebih rendah daripada di bulan Mei.

\section{Sistem Pengumpulan, Pemisahan dan Daur Ulang Sampah Kota Bandung}

Pengumpulan adalah bagian yang paling padat karya dan mahal dari infrastruktur sampah padat perkotaan Bandung. Secara umum, Indonesia belum mempunyai managemen pengelolaan sampah perkotaan yang baik di antara negara-negara di Asia. Di Bandung pengumpulan sampah padat perkotaan (SSP) dilakukan oleh pemerintah kota melalui BUMD yang khusus mengurusi masalah tersebut yaitu PD Kebersihan kota Bandung. SSP dikumpulkan dengan berbagai metode termasuk: 
a. Pengumpulan sampah rumah tangga dari pintu ke pintu, yang dilakukan oleh petugas yang berkerja antara tengah malam sampai pagi;

b. Petugas sampah mengumpulkan sampah di hotel, pasar dan pangkalan militer, lembaga, bank, restoran, toko dan pabrik setiap hari antara pukul 08:00 dan 17:00, dan mengangkutnya ke tempat pembuangan sampah dan fasilitas daur ulang atau pengomposan;

c. Kota Bandung telah menempatkan stasiun transfer/ tempat pembuangan sementara yang tetap di seluruh kota di mana warganya diminta untuk menempatkan barang daur ulang terpisah dari sampah rumah tangga mereka;

d. Kota Bandung menggunakan truk utnuk mengangkut sampah yang tidak dapat diolah maupun di jadikan kompos dari stasiun transfer ke tempat pembuangan final yang berlokasi di Sarimukti Cipatat Kabupaten Bandung Barat.

e. Kendaraan pengumpul sampah padat perkotaan mengumpulkan barang-barang berukuran besar sebagai tanggapan atas permintaan penghasil sampah.

Sampah padat perkotaan (SPP) umumnya terdiri dari sampah organik (misalnya sampah dapur, sampah taman, dan lain-lain), Sampah anorganik yang tidak dapat didaur ulang (misalnya abu batubara, arang, debu, dll.) Dan sampah yang dapat didaur ulang (misalnya plastik, kertas, dan lain-lain). Sekitar 44,3\% dari pengelolaan sampah padat di kota Bandung dikomposkan untuk menghasilkan bahan pupuk, 54,7\% ditolak dan dibuang di tempat pembuangan akhir. Sampah non organik sebesar $23 \%$ sebagian besar di daur ulang dan sekitar 11,3\% di bawa ke tempat pembuangan akhir, sementara sampah Residu seperti B3 sebesar $14 \%$ ditimbun (DLHK, 2018).

\section{Sistem Alternatif Masa Depan Pengelolaan Sampah Kota Bandung}

Sistem manajemen sampah dengan menggunakan pendekatan kumpul, angkut dan buang tidak cocok lagi diterapkan di kota Bandung. Hal ini disebabkan meode ini akan menyebabkan terjadinya penimbunan sampah yang semakin lama semakin jenuh. Yang pada akhirnya akan menambah permasalahan di tempat pembuangan akhir sampah (Surakusumah, 2008). Banyak teknologi pembuangan sampah dapat diterapkan pada kondisi di kota Bandung. Ini termasuk insinerasi dengan pemulihan energi, TPA, pengomposan dan sistem baru seperti pirolisis dan bahan bakar turunan sampah.

Insinerasi adalah metode umum untuk mengolah bahan sampah. Manfaat berikut ditawarkan untuk insinerasi sampah (Brunner, 1991): 
a. volume dan pengurangan berat menjadi sebagian kecil dari ukuran aslinya;

b. pengurangan sampah segera terjadi tidak diperlukan tempat tinggal jangka panjang di tempat pembuangan sampah;

c. pembakaran dapat dilakukan di lokasi tanpa perlu transportasi jarak jauh;

d. pembuangan udara ke atmosfer dapat dipantau dan dikendalikan;

e. residu abu itu steril;

f. bahkan sampah berbahaya seringkali dapat dihancurkan seluruhnya;

g. lahan yang relatif kecil dibutuhkan untuk insinerator dibandingkan dengan tempat pembuangan sampah;

h. energi biasanya dapat diperoleh kembali secara ekonomis dari proses insinerasi.

Beberapa kekurangannya antara lain:

a. biaya modal yang tinggi;

b. operator yang terlatihdiperlukan;

c. tidak semua bahan bisa terbakar;

d. bahan bakar tambahan mungkin diperlukan untuk mencapai efisiensi penghancuran yang dibutuhkan.

Insinerasi dipilih untuk mengurangi secara dramatis volume aliran sampah, menghancurkan racun dalam apa yang disebut sampah berbahaya, dan memulihkan energi dalam bentuk listrik dan uap. Insinerasi dapat mengurangi massa dan volume sampah $75 \%$ (massa) dan 90\% (volume). Keuntungan lain dari metode ini adalah lahan yang dibutuhkan tidak terlalu besar sehingga hemat dari segi pembiayaan juga (sewa lahan). Hal ini sangat cocok di implementasikan di kota bandung yang memang menghadapi masalah kekurangan lahan. Disamping itu hasil pembakaran sampah yang dilakukan melalui metode insinerasi dapat digunakan sebagai pembangkit listrik. Hal ini tentu jug akan menimbulkan keuntungan kareana dapat mengurangi ketergantungan kota Bandung dengan sumberdaya listrik yang ada.

Emang metode insinerasi ini mempunyai beberapa kelemahan seperti polusi udara yang ditimbulkan. Dalam sebuah penelitian yang dilakukan oleh Delaware Solid Waste Authority tahun 1994 menunjukkan dalam kadar energi yang sama yang dihasilkan, metode insinerasi menghasilkan SO2, HCL, CO dan NOx yang lebih besar dibandingkan pembangkit listrik yang berbahan bakar gas alam dan lebih kecil jika dibandingkan dengan pembangkit listrik dengan batubara sebagai sumberdaya. 
Terlepas dari itu semua metode insinerasi ini sangat tepat di implimentasikan di kota Bandung mengingat keterbatasan sumberdaya lahan yang sangat langka yang menyebabkan semakin tinggimya biaya pengelolaan sampah padat perkotaaan di kota Bandung terutama dalam hal sewa lahan untuk tempat pembuangan akhir.

\section{KESIMPULAN}

Meski tahapan awal dari rencana aksi strategis baru pengelolaan sampah berkelanjutan di Kota Bandung telah dilaksanakan selama 3 tahun terakhir, banyak masalah yang masih harus diselesaikan. Masalah utamanya adalah minimnya sarana berupa lahan dan alat angkut sampah yang masih belum sesuai dengan kebutuhan ditambah penegakan hukum oleh instansi terkait.

Insinerator sampah-ke-energi modern mencakup sistem canggih untuk secara substansial mengurangi emisi partikulat (yang mungkin mengandung logam berat) dan gas berbahaya, fitur yang diperlukan untuk menjaga lingkungan dan kesehatan masyarakat. Pejabat OWRC didesak untuk memasukkan peralatan pengendalian polusi udara yang sesuai sebagai bagian dari instalasi sampah menjadi energi yang akan dirancang, dibangun, dan dioperasikan di kota.

\section{DAFTAR PUSTAKA}

Ahsan, A., Alamgir, M., El-Sergany, M. M., Shams, S., Rowshon, M. K., \& Daud, N. N. (2014). Assessment of Municipal Solid Waste Management System in A Developing Country. Chinese Journal of Engineering, 2014(12a), 1-11.

Asase, M., Yanful, E. K., Mensah, M., Stanford, J., \& Amponsah, S. (2009). Comparison of Municipal Solid Waste Management Systems in Canada And Ghana: A Case Study of The Cities Of London, Ontario, And Kumasi, Ghana. Waste management, 29(10), 2779-2786.

Badan Pusat Statistik Kota Bandung (2018) Kota Bandung Dalam Angka 2018

Brunner, C. R. (1991). Biological Sludge Incineration. Waste Management, 11(3), 155-162.

Buclet, N., \& Godard, O. (Eds.). (2013). Municipal Waste Management In Europe: A Comparative Study In Building Regimes (Vol. 10). Springer Science \& Business Media.

Burnley, S., Phillips, R., Coleman, T., \& Rampling, T. (2011). Energy implications of the thermal recovery of biodegradable municipal waste materials in the United Kingdom. Waste Management, 31(9-10), 1949-1959.

Damanhuri, E., \& Padmi, T. (2010). Pengelolaan Sampah. Diktat kuliah TL, 3104, 5-10. 
Das, S., \& Bhattacharyya, B. K. (2013). Municipal Solid Waste Characteristics and Management in Kolkata, India. In The 19th International Conference on Industrial Engineering and Engineering Management (pp. 1399-1409). Springer, Berlin, Heidelberg.

Dwiyanto, B. M. (2011). Model Peningkatan Partisipasi Masyarakat dan Penguatan Sinergi dalam Pengelolaan Sampah Perkotaan. Jurnal Ekonomi Pembangunan: Kajian Masalah Ekonomi dan Pembangunan, 12(2), 239-256.

Giannis, A., Chen, M., Yin, K., Tong, H., \& Veksha, A. (2017). Application of System Dynamics Modeling for Evaluation of Different Recycling Scenarios in Singapore. Journal of Material Cycles and Waste Management, 19(3), 1177-1185.

Hasibuan, R. (2016). Analisis Dampak Sampah/Sampah Rumah Tangga Terhadap Pencemaran Lingkungan Hidup. Jurnal Ilmiah Advokasi, 4(1), 42-52.

Indonesia, P. R. (2008). Undang-undang Republik Indonesia Nomor 18 Ttahun 2008 tentang pengelolaan sampah. Sekretariat Negara, Jakarta.

Jouhara, H., Czajczyńska, D., Ghazal, H., Krzyżyńska, R., Anguilano, L., Reynolds, A. J., \& Spencer, N. (2017). Municipal Waste Management Systems for Domestic Use. Energy, 139, 485-506.

Marliani, N. (2015). Pemanfaatan Sampah Rumah Tangga (Sampah Anorganik) sebagai Bentuk Implementasi dari Pendidikan Lingkungan Hidup. Formatif: Jurnal Ilmiah Pendidikan MIPA, 4(2).

Narayana, T. (2009). Municipal Solid Waste Management in India: From Waste Disposal to Recovery of Resources? Waste management, 29(3), 1163-1166.

Omran, A., \& Gavrilescu, M. (2008). Municipal Solid Waste Management in Developing Countries: A Perspective on Vietnam. Environmental Engineering \& Management Journal (EEMJ), 7(4).

Sari, P. N. (2017). Analisis Pengelolaan Sampah Padat di Kecamatan Banuhampu Kabupaten Agam. Jurnal Kesehatan Masyarakat Andalas, 10(2), 157-165.

Sejati, K. (2009). Pengolahan Sampah Terpadu. Kanisius.

Sudaryanto, S., Yusriah, K., \& Andesta, E. T. (2009). Studi Komparatif Kebijakan Pengelolaan Sampah Elektronik Di Negara Berkembang. ET Andesta

Sugiyono, P. D. (2010). Metode Penelitian Kuantitatif dan Kualitatif. Bandung: CV Alfabeta.

Sulistyorini, L. (2005). Pengelolaan Sampah dengan Cara Menjadikannya Kompos. Jurnal Kesehatan Lingkungan, 2(1).

Surakusumah, W. (2008). Permasalahan Sampah Kota Bandung dan Alternatif Solusinya. Universitas Pendidikan Indonesia, Jurusan Biologi.

Thi, N. B. D., Kumar, G., \& Lin, C. Y. (2015). An Overview of Food Waste Management in Developing Countries: Current Status and Future Perspective. Journal of Environmental Management, 157, 220-229.

Wahyono, S. (2001). Pengelolaan Sampah Kertas di Indonesia. Jurnal Teknologi Lingkungan, 2(3).

Wilson, D. C., Velis, C., \& Cheeseman, C. (2006). Role Of Informal Sector Recycling In Waste Management In Developing Countries. Habitat international, 30(4), 797-808. 